\title{
AN APPLICATION OF AHP TO INVESTMENT PORTFOLIO SELECTION IN THE BANKING SECTOR OF THE NIGERIAN CAPITAL MARKET
}

\author{
E. O. Oyatoye* \\ Faculty of Business Administration \\ University of Lagos, Akoka - Yaba, Lagos, Nigeria \\ E-mail: olateju_2006@yahoo.co.uk \\ G. U. Okpokpo \\ Centre for Management Development \\ Shangisha, Lagos, Nigeria \\ E-mail: utexnig@yahoo.com \\ G. A. Adekoya \\ Faculty of Business Administration \\ University of Lagos, Akoka - Yaba, Lagos, Nigeria \\ E-mail: adebolaadekoya@yahoo.com
}

\begin{abstract}
The importance of investment to the individual, a nation and world economy cannot be over emphasized. Investment involves the sacrifice of immediate consumption to achieve greater consumption in the future. Western economies has emphasized saving and investment as the engine of economic growth.

The Nigerian banking sector has made tremendous success in the recent past. All the banks that approached the capital market via public offers and right issues to raise their capital base recorded huge success. Apart from the fact that banks are experiencing structural expansion and high -posted profits, the investors in bank stocks are also enjoying high returns on investment, despite the slow growth in the nation's economy. However, the recent financial crisis that started in America, which has caused economy meltdown in many nations of the world and sudden fall in share prices, has brought about a higher risk than envisaged on investors, particularly those investing in bank stocks. Hence, great care and monitoring is required on the part of investors to ensure that fund invested does not go down the drain.
\end{abstract}

This paper applies the Analytic Hierarchy Process to determine the importance of the various criteria, factors and alternatives that are very essential to successful investment decisions in the face of the current recession.

Keywords: Application, AHP, investment, portfolio selection, capital market.

Corresponding author 


\section{Introduction}

In investment decision making in the capital market, especially the banking sector stocks and all types of investment, time and risks are critical variables to be considered. The preliminary information needed when taking investment decisions are:

- The size of capital or how much to be invested

- The cost of capital on the opportunity cost of the amount to be invested

- The rate of returns on capital or payoffs from investment.

According to Akintoye (1999), "in evaluating investments and potential investments, the relevant factors to be considered are liquidity; safety; structure; yield; and growth". The banking sector had made tremendous success in the recent past as all the banks that approached the capital market via public offers and right issues to raise their capital base made huge success. The re-capitalization success of the banks was almost simultaneously followed by increased demand for banking sector stocks thereby giving rise to increased market prices of banking shares, increased earnings and total market turnover greater than $300 \%$ being highest among all sectors stocks. However, the primary challenges to an investor in banking sectors would be to know:

- Which of the banks stocks should be accepted now and for the future?

- What total amount of capital or money should one invest and for which stock?

- How should theportfolio of stocks options be financed?

"The decision about portfolio choice and the acquisition of funds ideally must be made simultaneously. Similarly, a yardstick for project or portfolio acceptance cannot be set without considering the cost of funds to the investor, and this cost will be influenced by the characteristics of the investment opportunities available to the investor", Bromwich (1981). Developments, since the Second World War have stimulated the search for criteria or systematic decision rules for investment appraisal. Observably, rapid economic growth and technology progress have vastly increased the investment opportunities available to prospective investors having only limited funds.

Although rapid technology advancement had tended to increase the lag between decision-making and the benefits of these decisions, advances in economic forecasting, econometrics and budgetary control have made the prediction and measurement of receipts and costs easier. Practically, we have myriads of investment criteria, viz: the Net Present Value, Internal Rate of Returns, Benefits -Less-Cost, Benefit/Cost Ratio, the Payback period, the rule of thumb, and so on. These are various methods of investment appraisal, still many problems do affect the level of accuracy on predictability of the several investment appraisal. Dominant among these problems is the lack of sound theoretical and operational way of handling the problem of uncertainty, which tend to render useless relevant estimates and predictions. Although model building and adaptation comes to help in this regard, but that is only when there are spelt out hypothesis and assumptions, which are often unrealistic, and when subjected to empirical test may exhibit lag between decisions and outcomes.

As part of advancement in the search for decision making techniques, especially those involving uncertainty and human value judgement, Saaty (1980) developed the Analytical Hierarchy Process (AHP). This study adopts the AHP in making decision on investment portfolio selection in the banking sector of the Nigerian capital market.

\subsection{The problem}

The banking industry in Nigeria has for some time been experiencing boom. Apart from fact that banks are experiencing structural expansion and high-posted profits, the investors in bank stocks are also enjoying high returns, on investment - in spite of the slow growth in the nation's economy, particularly the real sectors such as agriculture, industry, construction, and so on. Although, commerce and petroleum sectors are currently enjoying banking sector credit patronage, the two sectors have their own inherent volatility. The major problems needing urgent investigation are: 
- Will the current boom in the banking sector continue, in the medium to long term, in the absence of real sector development?

- How realistic are the current annual profit declarations of banks in Nigeria?

- What will be the consequences on bank stocks returns for any eventual drop in the profit performance of the banks and the concomitant fall in bank stocks prices?

- Which banks are likely to withstand financial market shocks and emerge the sector leaders?

These questions tend to highlight a critical issue that there exist disconnect between bank sector performance and the real sector of the Nigerian economy. This is at variance with what obtains in the developed economies, as well as a defeat of the macroeconomic policy visions for consolidating the banking sector. Also, investors in bank stocks may face higher risk than may be envisaged if investment plans are not well monitored. The recent financial crisis that has led to economy meltdown in many countries is already taking its toll on Nigerian economy as almost all companies share prices have crashed to an unbelievable level. The banking sector could, therefore, suffer contraction if Nigeria fails to urgently ensure total development of the entire key economic sectors as the petroleum, commerce and communication sectors alone cannot meaningfully sustain the banking sector. There could yet be an imminent shock, if for any reason the Central Bank insists on policy streamlining banking operations, for all banks to render financial-end-of-year-reports at same time. The need to avert investor's loss in the short, medium to long-term necessitates this study.

\subsection{Objective of the study}

At the micro level, the investors are in business to maximize returns for a given degree of risks or minimize risks for a given expected returns. At the macro level, effectiveness of economic policy is measured in terms of the impact on the real economy aggregates. Thus, this study is embarked upon to achieve the following objectives:

- Critically evlauate the performance of the banking sector in relation to stock investment returns;

- Determine the level of stability of the current banking sector boom in Nigeria especially in light of recent economy meltdown;

- Make a comparative assessment of the risks and returns associated with investment among the banks stocks in Nigeria;

- Suggest investment rules that will help mitigate loss of investment returns in capital market;

- Determine the necessary criteria relevant for investment decisions in banks stocks in the shortterm, medium- term and long-term.

- Demonstrate an efficient and effective investment decision approach in stock market using the AHP method;

- Proffer advice toward efficient stock market portfolio management.

\section{Review of related studies}

Bolster; Janjigian and Trahan (2005) use AHP to determine investor suitability, based on age, to select among seven investment securities. The results of their study showed varying pattern of investment for the different age groups. Kurz; Jin and Motolese (2003) investigate the determinants of stock market volatility and risk premium. The study highlighted the significance of investor's expectation on stock prices and interest rate affecting investment in stocks.

Richard and Mukhtan (2008) use time series analysis and portfolio selection on mutual savings banks to determine the optimal portfolio choice. They opined that 'an investor should invest in short- term stocks, risk-less assets, and well diversified investment to achieve the highest utility from investable fund. Meziani (2003) investigates the effect of investment barriers on international capital flows using expert driven system. The study adopts the AHP method to determine the critical investment barriers affecting foreign capital flows as well as national markets situations. The hierarchy of Optimal Investment Portfolio (OIP) criteria was used to develop an AHP structure. The OIP is a frictionless portfolio characterized by an absence of regulatory obstacles, information asymmetries, capital controls, and all such barriers that restrain cross-border investment. However, national market (both 
macro and micro) environment do affect international investment. The study concludes that among all such impediments, political risks, legal restrictions, liquidity risks, discriminatory taxation and psychological barriers are the critical macro variables more dominant than micro impediments.

\section{Methodology}

The Analytic Hierarchy Process (AHP) technique of solving problem, which explicitly recognizes and incorporates the knowledge and expertise of the participants in the priority setting process making use of their subjective preferences was adapted as the research methodology. Due to the peculiarity of the AHP technique, a logical procedure for making decision is to make use of primary data. Thus, the data used in the study is the response of investors in banking stocks (based on their scale of preferences) as in the questionnaire distributed.

The population of the study consists of the 24 banks that emerged after the consolidation exercise of 2005. Twelve of these banks were selected using random sampling technique to ensure a good representation of the population. The twelve banks and the notation used for each of them in the study are: Access Bank Plc (AB), AfriBank Plc (AFB), Diamond Bank (DB); First Bank Plc (FB); Guaranty Trust Bank Plc (GTB); Intercontinental Bank Plc (ICB); Oceanic Bank Plc (OB); Platinum Habib Bank Plc (PHB); Skye Bank Plc (SKB); Union Bank plc (UB); United Bank for Africa Plc (UBA); and Zenith Bank Plc (ZB).

Also, given the improved awareness and participation of Nigerians in stock business (buying and selling), the population of those involved had become too large to be covered in a single study as this. Hence, opinions were sort from 750 respondents among different income groups using the judgmental random sampling technique among different income groups. Also to buttress the quality of the findings of the study, the researchers used random sampling techniques to select five (5) corporate investment organization (that is stock broking firms and capital market investment companies) which include BGL Securities Limited; Rostrum Investment and Security Limited; Hedge Securities Investment Co. Limited; Davandy Financial and Security Limited; and Lagos Stock Exchange.

Questionnaire was designed using the dichotomous or two-way questions, and questions based on Saaty's scale of preference - a form of Likert scaled type question generally adopted for the application of AHP technique wee administered on individual investors and the investment firms.. Section A and B of the questionnaire consist of questions on the demography of individual investors and the corporate investment organizations, respectively; while section $\mathrm{C}$ dealt with the subject matter. For each corporate investment firms, 5 questionnaires were distributed thus numbering 25 questionnaires. 750 questionnaires were distributed to the individual investors at 250 to each of low income, middle income and high income investors respectively.

\subsection{Developing the model.}

\subsubsection{Model formulation.}

The key problem of this study is to ensure the maximization of investment returns from bank stocks through strategic investment decisions either by speculation (short-term trading), medium-term or long-term investment plan. The problem formulation thus entails:

- Identifying the objective to be achieved: Maximisation of Bank Stocks' Investment Returns.

- Identification of factors that affect the objective.

These factors are:

i) The banks under consideration for investment

ii) The criteria considered necessary for portfolio investment among bank -sector stocks, which are

- Financial criteria $(\mathrm{F})$

- Capital market indices (C)

- Management efficiency (M)

- Technology criteria (T) 
iii) The sub-criteria considered as factors that influence the criteria necessary for portfolio investment are:

(a) Financial criteria -------- F Asset base -- A, Gross earnings ---- Q, Profit after tax ---- T, Share capital holders fund ---- S

(b) Capital market indices -------- C

Share price --- P, Earning per share---- E, Market capitalisation --- K, Bonus ratio polciy --- B, Dividends policy ------ D

(c) Management efficiency criteria -------- M

Credit policy---- R, Corporate image --- I, Structure and strategy --- W, Human capacity --- H, Age (generation) of bank ---- G

(d) Technology criteria ---------- T

I. T. Capability ----- J, Products/ innovation ----- N, Locations/spread ------ L

iv) The alternative investment plans that would generally maximize returns are:

- Speculative (short-term) investment plan for one year and below.

- Medium-term investment plan for period above one year but less than 5 years.

- Long-term investment plan for period 5 years and above.

\subsubsection{The AHP model for the study}

The AHP technique adopts diagrammatic representation in the form of hierarchy to model real-life situation. Here, the structure identified at the problem formulation stage is put in a generalized form using general concepts, notations and symbols. The model for this study has five levels as follows:

Level I: The objective (maximizing banks' stocks investment returns).

Level II: The banks considered in achieving the objective

Level III: The main criteria considered necessary to achieve the objective.

Level IV: Sub-criteria that will lead to the achievement of the objective.

Level V: The alternative to be used to achieve the objective. 
Level I: Overall Goal

Max Banks Stocks Investment Returns

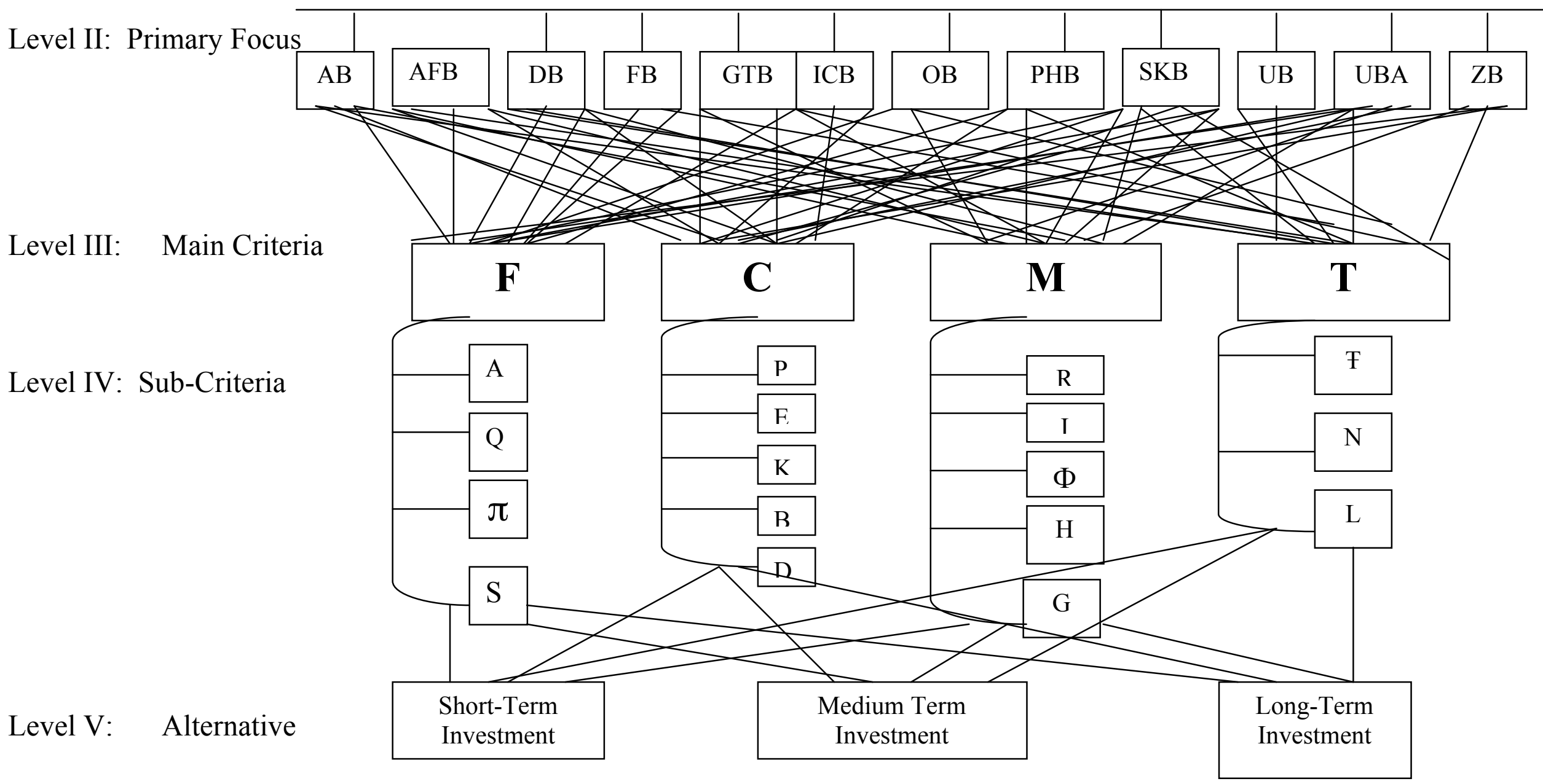

Fig. 3.1: A Hierarchy of Banks Stocks Investment Decision to Maximize Returns. 


\subsection{Data analysis technique}

The data generated through the questionnaire were analyzed with the aid of the AHP software package "Expert Choice". Expert choice is a computer software package that performs the computation required by the AHP. It is a system for the analysis, synthesis and justification of complex decisions and evaluations. In the program, data is organized in a logical structure, and the user understands and/or experience is used to make pair-wise comparisons about the relative importance. With respect to the goal, these factors span a descent tree of criteria, sub-criteria, factors and alternatives. Expert choice uses the supplied data to device global priorities and informs the user of the consistency of the relative comparisons fed it. Furthermore, it provides reports, histograms and sensitivity analysis as the user wishes.

\section{Analysis of results}

We proceed by making comparisons between criteria and alternatives, a pair at a time to determine the relative weights. The eigenvalue method, mean transformation or row geometric mean become helpful for the mathematical computation of the relative weights. The pair-wise comparisons are based on nine-point -wise comparisons and the scale value for the pair-wise comparisons and the scale value for the pair-wise comparisons is the set $9,8,7,6,5,4,3,2,1,1 / 2,1 / 3,1 / 4,1 / 5,1 / 6,1 / 7,1 / 8,1 / 9$. Expert choice package was invaluable in providing not only priorities, but also consistency of the relative comparisons, sensitivity analysis and summary reports, while Mathcard software was used to compute the eigenvalues and eigenvectors which aided the computation of consistency ratios of the variables.

Furthermore, since the twelve selected banks operate in the same economy, under the same financial regulations and dully consolidated, they were regarded comparable and equally ranked. Thus, each of them was given a rating of .083 . Also, considering the sub-criteria with respect to the decision alternatives as they apply to the individual banks, the priorities are the same across the selected banks. In this regard, the priority used for short-term, medium term and long-term plans remain the same for all the twelve banks. However, considering the investment in the stocks of each bank given the principal criteria, the priorities vary from one bank to another as revealed in the various computations. 
Table 4.1: Judgment matrix of alternatives with respect to sub-criteria

\begin{tabular}{|c|c|c|c|c|}
\hline Sub-Criteria & Alternative & $\begin{array}{l}\text { Short-Term } \\
\text { Investment }\end{array}$ & $\begin{array}{l}\text { Medium-Term } \\
\text { Investment }\end{array}$ & $\begin{array}{l}\text { Long-Term } \\
\text { Investment }\end{array}$ \\
\hline \multirow[t]{3}{*}{ Asset base } & Short-term & 1 & 5 & 7 \\
\hline & Medium -term & $1 / 5$ & 1 & 3 \\
\hline & Long-term & $1 / 7$ & $1 / 3$ & 1 \\
\hline \multirow[t]{3}{*}{ Gross Earning } & Short-term & 1 & 3 & 5 \\
\hline & Medium-term & $1 / 3$ & 1 & 3 \\
\hline & Long-term & $1 / 5$ & $1 / 3$ & 1 \\
\hline \multirow[t]{3}{*}{ Profit after tax } & Short-term & 1 & $1 / 3$ & 2 \\
\hline & Medium-term & 3 & 1 & 5 \\
\hline & Long-term & $1 / 2$ & $1 / 5$ & 1 \\
\hline \multirow[t]{3}{*}{ Share capital holders fund } & Short-term & 1 & $1 / 3$ & $1 / 5$ \\
\hline & Medium-term & 3 & 1 & $1 / 3$ \\
\hline & Long-term & 5 & 3 & 1 \\
\hline \multirow[t]{3}{*}{ Share price } & Short-term & 1 & 2 & 9 \\
\hline & Medium-term & $1 / 2$ & 1 & 7 \\
\hline & Long-term & $1 / 9$ & $1 / 7$ & 1 \\
\hline \multirow[t]{3}{*}{ Earning per share } & Short-term & 1 & 2 & 9 \\
\hline & Medium-term & $1 / 2$ & 1 & 5 \\
\hline & Long-term & $1 / 9$ & $1 / 5$ & 1 \\
\hline \multirow[t]{3}{*}{ Market Capitalization } & Short-term & 1 & 2 & 3 \\
\hline & Medium-term & $1 / 2$ & 1 & 2 \\
\hline & Long-term & $1 / 3$ & $1 / 2$ & 1 \\
\hline \multirow[t]{3}{*}{ Bonus Ratio Policy } & Short-term & 1 & 1 & 1 \\
\hline & Medium-term & 1 & 1 & 1 \\
\hline & Long-term & 1 & 1 & 1 \\
\hline \multirow[t]{3}{*}{ Dividend Policy } & Short-term & 1 & $1 / 5$ & $1 / 9$ \\
\hline & Medium-term & 5 & 1 & $1 / 2$ \\
\hline & Long-term & 9 & 2 & 1 \\
\hline \multirow[t]{3}{*}{ Credit Policy } & Short-term & 1 & 3 & 5 \\
\hline & Medium-term & $1 / 3$ & 1 & 3 \\
\hline & Long-term & $1 / 5$ & $1 / 3$ & 1 \\
\hline Sub-Criteria & Alternative & $\begin{array}{l}\text { Short-Term } \\
\text { Investment }\end{array}$ & $\begin{array}{l}\text { Medium-Term } \\
\text { Investment }\end{array}$ & $\begin{array}{l}\text { Long-Term } \\
\text { Investment }\end{array}$ \\
\hline \multirow[t]{3}{*}{ Corporate Image } & Short-term & 1 & 2 & 2 \\
\hline & Medium-term & $1 / 2$ & 1 & 2 \\
\hline & Long-term & $1 / 2$ & $1 / 2$ & 1 \\
\hline \multirow[t]{3}{*}{ Structure / Strategy } & Short-term & 1 & 2 & 2 \\
\hline & Medium-term & $1 / 2$ & 1 & 2 \\
\hline & Long-term & $1 / 2$ & $1 / 2$ & 1 \\
\hline \multirow[t]{3}{*}{ Human Capacity } & Short-term & 1 & 2 & 2 \\
\hline & Medium-term & $1 / 2$ & 1 & 2 \\
\hline & Long-term & $1 / 2$ & $1 / 2$ & 1 \\
\hline \multirow{3}{*}{ Age of bank } & Short-term & 1 & $1 / 3$ & $1 / 5$ \\
\hline & Medium-term & 3 & 1 & $1 / 3$ \\
\hline & Long-term & 5 & 3 & 1 \\
\hline I.T Capability & Short-term & 1 & 2 & 2 \\
\hline
\end{tabular}




\begin{tabular}{|l|c|c|c|c|}
\hline & Medium-term & $1 / 2$ & 1 & 2 \\
\hline & Long-term & $1 / 2$ & $1 / 2$ & 1 \\
\hline Product Innovation & Short-term & 1 & $1 / 2$ & $1 / 3$ \\
\hline & Medium-term & 2 & 1 & $1 / 3$ \\
\hline & Long-term & 3 & 3 & 1 \\
\hline Location/Spread & Short-term & 1 & $1 / 2$ & $1 / 7$ \\
\hline & Medium-term & 2 & 1 & $1 / 5$ \\
\hline & Long-term & 7 & 5 & 1 \\
\hline
\end{tabular}

Table 4.3: Judgment matrices of the main criteria

\begin{tabular}{|c|c|c|c|c|}
\hline & $\mathbf{F}$ & $\mathbf{C}$ & $\mathbf{M}$ & $\mathbf{T}$ \\
\hline $\mathrm{F}$ & 1 & 2 & 2 & 2 \\
\hline $\mathrm{C}$ & $1 / 2$ & 1 & 2 & 2 \\
\hline $\mathrm{M}$ & $1 / 2$ & $1 / 2$ & 1 & 2 \\
\hline $\mathrm{T}$ & $1 / 2$ & $1 / 2$ & $1 / 2$ & 1 \\
\hline
\end{tabular}

\begin{tabular}{|c|c|c|c|c|}
\hline & $\mathbf{F}$ & $\mathbf{C}$ & $\mathbf{M}$ & $\mathbf{T}$ \\
\hline $\mathrm{F}$ & 1 & 5 & 5 & 3 \\
\hline $\mathrm{C}$ & $1 / 5$ & 1 & 2 & 2 \\
\hline $\mathrm{M}$ & $1 / 5$ & $1 / 2$ & 1 & 2 \\
\hline $\mathrm{T}$ & $1 / 3$ & $1 / 2$ & $1 / 2$ & 1 \\
\hline
\end{tabular}

Judgment matrix expressed by the respondents

Judgment matrix expressed by respondents in respect in respect of Diamond Bank, Guaranty Trust Bank, of First Bank Skye Bank and Union Bank.

\begin{tabular}{|c|c|c|c|c|}
\hline & $\mathbf{F}$ & $\mathbf{C}$ & $\mathbf{M}$ & $\mathbf{T}$ \\
\hline $\mathrm{F}$ & 1 & 2 & 2 & 2 \\
\hline $\mathrm{C}$ & $1 / 2$ & 1 & 2 & 2 \\
\hline $\mathrm{M}$ & $1 / 2$ & $1 / 2$ & 1 & $1 / 3$ \\
\hline $\mathrm{T}$ & $1 / 2$ & $1 / 2$ & 3 & 1 \\
\hline
\end{tabular}

\begin{tabular}{|c|c|c|c|c|}
\hline & $\mathbf{F}$ & $\mathbf{C}$ & $\mathbf{M}$ & $\mathbf{T}$ \\
\hline $\mathrm{F}$ & 1 & 3 & 3 & 2 \\
\hline $\mathrm{C}$ & $1 / 3$ & 1 & 2 & 2 \\
\hline $\mathrm{M}$ & $1 / 3$ & $1 / 2$ & 1 & 2 \\
\hline $\mathrm{T}$ & $1 / 2$ & $1 / 2$ & $1 / 2$ & 1 \\
\hline
\end{tabular}

Judgment matrix of respondents in respect of Afribank Plc.

\begin{tabular}{|c|c|c|c|c|}
\hline & $\mathbf{F}$ & $\mathbf{C}$ & $\mathbf{M}$ & $\mathbf{T}$ \\
\hline $\mathrm{F}$ & 1 & 2 & 2 & 2 \\
\hline $\mathrm{C}$ & $1 / 2$ & 1 & 2 & 2 \\
\hline $\mathrm{M}$ & $1 / 2$ & $1 / 2$ & 1 & 2 \\
\hline $\mathrm{T}$ & $1 / 2$ & $1 / 2$ & $1 / 2$ & 1 \\
\hline
\end{tabular}

Judgment matrix of respondents in respect of Oceanic Bank

\begin{tabular}{|c|c|c|c|c|}
\hline & $\mathbf{F}$ & $\mathbf{C}$ & $\mathbf{M}$ & $\mathbf{T}$ \\
\hline $\mathrm{F}$ & 1 & 2 & 2 & 2 \\
\hline $\mathrm{C}$ & $1 / 2$ & 1 & 2 & 2 \\
\hline $\mathrm{M}$ & $1 / 2$ & $1 / 2$ & 1 & 2 \\
\hline $\mathrm{T}$ & $1 / 2$ & $1 / 2$ & $1 / 2$ & 1 \\
\hline
\end{tabular}

Judgment matrix of respondents in respect of Platinum Habib Bank.

Judgment matrix of respondents in respect of Intercontinental Bank.

\begin{tabular}{|c|c|c|c|c|}
\hline & $\mathbf{F}$ & $\mathbf{C}$ & $\mathbf{M}$ & $\mathbf{T}$ \\
\hline $\mathrm{F}$ & 1 & $1 / 2$ & 2 & 3 \\
\hline $\mathrm{C}$ & 2 & 1 & 5 & 5 \\
\hline $\mathrm{M}$ & $1 / 2$ & $1 / 5$ & 1 & 3 \\
\hline $\mathrm{T}$ & $1 / 3$ & $1 / 5$ & $1 / 3$ & 1 \\
\hline
\end{tabular}

Judgment matrix of respondents in respect of United Bank for Africa.

\begin{tabular}{|c|c|c|c|c|}
\hline & $\mathbf{F}$ & $\mathbf{C}$ & $\mathbf{M}$ & $\mathbf{T}$ \\
\hline $\mathrm{F}$ & 1 & 3 & 3 & 3 \\
\hline $\mathrm{C}$ & $1 / 3$ & 1 & 2 & 2 \\
\hline $\mathrm{M}$ & $1 / 3$ & $1 / 2$ & 1 & 2 \\
\hline $\mathrm{T}$ & $1 / 3$ & $1 / 2$ & $1 / 2$ & 1 \\
\hline
\end{tabular}

Judgment matrix of respondents in respect of Access Bank. 


\begin{tabular}{|c|c|c|c|c|}
\hline & F & $\mathbf{C}$ & $\mathbf{M}$ & $\mathbf{T}$ \\
\hline $\mathrm{F}$ & 1 & 3 & 3 & 9 \\
\hline $\mathrm{C}$ & $1 / 3$ & 1 & 3 & 6 \\
\hline $\mathrm{M}$ & $1 / 3$ & $1 / 3$ & 1 & 3 \\
\hline $\mathrm{T}$ & $1 / 9$ & $1 / 6$ & $1 / 3$ & 1 \\
\hline
\end{tabular}

Judgment matrix of respondents in respect of Zenith Bank

Table 4.2: Judgment matrix of sub-criteria in respect of sub-criteria

\begin{tabular}{|c|c|c|c|c|c|c|}
\hline Main Criteria & Sub-criteria & $\begin{array}{c}\text { Asset } \\
\text { base }\end{array}$ & $\begin{array}{c}\text { Gross } \\
\text { earning }\end{array}$ & $\begin{array}{c}\text { Profit after } \\
\text { tax }\end{array}$ & $\begin{array}{c}\text { Share } \\
\text { capital fund }\end{array}$ & \\
\hline \multirow[t]{4}{*}{ Financial Criteria } & Asset Base & 1 & 3 & $1 / 5$ & $1 / 2$ & \\
\hline & Gross Earning & $1 / 3$ & 1 & $1 / 5$ & $1 / 5$ & \\
\hline & Profit After Tax & 5 & 5 & 1 & 2 & \\
\hline & Share Capital Fund & 2 & 5 & $1 / 2$ & 1 & \\
\hline \multirow[t]{6}{*}{$\begin{array}{l}\text { Capital Market } \\
\text { Indices }\end{array}$} & & $\begin{array}{c}\text { Share } \\
\text { price }\end{array}$ & $\begin{array}{c}\text { Earning per } \\
\text { share }\end{array}$ & $\begin{array}{c}\text { Market } \\
\text { capitalizatio } \\
\mathbf{n}\end{array}$ & $\begin{array}{c}\text { Bonus ratio } \\
\text { policy }\end{array}$ & $\begin{array}{l}\text { Dividend } \\
\text { policy }\end{array}$ \\
\hline & Share Price & 1 & 2 & 7 & 3 & 6 \\
\hline & Earning Per Share & $1 / 2$ & 1 & 7 & 2 & 3 \\
\hline & Market capitalization & $1 / 7$ & $1 / 7$ & 1 & $1 / 3$ & $1 / 3$ \\
\hline & Bonus ratio Policy & $1 / 3$ & $1 / 2$ & $1 / 3$ & 1 & 7 \\
\hline & Dividend Policy & $1 / 6$ & 3 & 3 & $1 / 7$ & 1 \\
\hline \multirow[t]{7}{*}{$\begin{array}{l}\text { Management } \\
\text { Efficiency Criteria }\end{array}$} & & $\begin{array}{l}\text { Credit } \\
\text { policy }\end{array}$ & $\begin{array}{l}\text { Corporate } \\
\text { image }\end{array}$ & $\begin{array}{l}\text { Structure } \\
\text { \&Strategy }\end{array}$ & $\begin{array}{l}\text { Human } \\
\text { capacity }\end{array}$ & $\begin{array}{l}\text { Age of } \\
\text { bank }\end{array}$ \\
\hline & Credit policy & 1 & 3 & 3 & 2 & 7 \\
\hline & Corporate image & $1 / 3$ & 1 & 2 & 2 & 7 \\
\hline & Structure \& Strategy & $1 / 3$ & $1 / 2$ & 1 & 2 & 5 \\
\hline & Human capacity & $1 / 2$ & $1 / 2$ & $1 / 2$ & 1 & 5 \\
\hline & Age of bank & $1 / 7$ & $1 / 7$ & $1 / 5$ & $1 / 5$ & 1 \\
\hline & & & $\begin{array}{c}\text { I.T. } \\
\text { Capacity }\end{array}$ & $\begin{array}{c}\text { Products } \\
\text { innovation }\end{array}$ & \multicolumn{2}{|c|}{ Location \& Spread } \\
\hline \multirow[t]{3}{*}{$\begin{array}{l}\text { Technology } \\
\text { Criteria }\end{array}$} & I.T. Capacity & & 1 & 2 & \multicolumn{2}{|c|}{9} \\
\hline & Product Innovation & & $1 / 2$ & 1 & \multicolumn{2}{|c|}{5} \\
\hline & Location/Spread & & $1 / 9$ & $1 / 5$ & 1 & \\
\hline
\end{tabular}


4.1 Analysis of priority in respect of the main criteria

Table 4.4: Priorities of the main criteria in respect of the primary focus

\begin{tabular}{|c|c|c|c|c|c|c|c|c|c|c|c|c|}
\hline \multirow[b]{2}{*}{ Main Criteria } & \multicolumn{12}{|c|}{ Primary Focus (Bank) } \\
\hline & AB & AFB & DB & FB & GTB & ICB & OB & PHB & SKB & UB & UBA & ZB \\
\hline Financial Criteria & .490 & .383 & .391 & .580 & .391 & .461 & .431 & .341 & .391 & .458 & .253 & .538 \\
\hline Capital Market Indices & .231 & .273 & .276 & .182 & .276 & .236 & .246 & .276 & .276 & .240 & .523 & .280 \\
\hline Managerial Efficiency & .163 & .125 & .195 & .130 & .195 & .168 & .189 & .195 & .195 & .185 & .148 & .134 \\
\hline Technology Criteria & .116 & .219 & .138 & .108 & .138 & .135 & .135 & .138 & .138 & .116 & .076 & .048 \\
\hline
\end{tabular}

Table 4.4 contains the preference values for the main criteria with respect to the primary focus. The preference ratios show that respondents considered financial criterion as most critical in terms of investing in the stocks of most of the selected banks except UBA. Respondents would opt for capital market indices before investing in the stock of UBA.

Table 4.5: Priorities of sub-criteria in respect of the main criteria by bank

\begin{tabular}{|c|c|c|c|c|c|c|c|c|c|c|c|c|c|}
\hline \multirow[b]{2}{*}{ Main criteria } & \multirow[b]{2}{*}{ Sub-criteria } & \multicolumn{12}{|c|}{ Bank } \\
\hline & & $\mathbf{A B}$ & AFB & DB & FB & GTB & ICB & OB & PHB & SKB & UB & UBA & ZB \\
\hline \multirow[t]{4}{*}{ Financial } & $\mathbf{A}$ & .142 & .142 & .142 & .142 & .142 & .142 & .142 & .142 & .142 & .142 & .142 & .142 \\
\hline & $\mathbf{Q}$ & .066 & .066 & .066 & .066 & .066 & .066 & .066 & .066 & .066 & .066 & .066 & .066 \\
\hline & $\pi$ & .513 & .513 & .513 & .513 & .513 & .513 & .513 & .513 & .513 & .513 & .513 & .513 \\
\hline & $\mathbf{S}$ & .279 & .279 & .279 & .279 & .279 & .279 & .279 & .279 & .279 & .279 & .279 & .279 \\
\hline \multirow[t]{5}{*}{ Capital Market Indices } & $\mathbf{P}$ & .429 & .429 & .429 & .429 & .429 & .429 & .429 & .429 & .429 & .429 & .429 & .429 \\
\hline & $\mathbf{F}$ & .196 & .196 & .196 & .196 & .196 & .196 & .196 & .196 & .196 & .196 & .196 & .196 \\
\hline & $\mathbf{K}$ & .045 & .045 & .045 & .045 & .045 & .045 & .045 & .045 & .045 & .045 & .045 & .045 \\
\hline & B & .261 & .261 & .261 & .261 & .261 & .261 & .261 & .261 & .261 & .261 & .261 & .261 \\
\hline & D & .070 & .070 & .070 & .070 & .070 & .070 & .070 & .070 & .070 & .070 & .070 & .070 \\
\hline \multirow[t]{5}{*}{ Managerial Efficiency } & $\mathbf{R}$ & .415 & .415 & .415 & .415 & .415 & .415 & .415 & .415 & .415 & .415 & .415 & .415 \\
\hline & I & .239 & .239 & .239 & .239 & .239 & .239 & .239 & .239 & .239 & .239 & .239 & .239 \\
\hline & $\mathbf{W}$ & .170 & .170 & .170 & .170 & .170 & .170 & .170 & .170 & .170 & .170 & .170 & .170 \\
\hline & $\mathbf{H}$ & .140 & .140 & .140 & .140 & .140 & .140 & .140 & .140 & .140 & .140 & .140 & .140 \\
\hline & G & .037 & .037 & .037 & .037 & .037 & .037 & .037 & .037 & .037 & .037 & .037 & .037 \\
\hline \multirow[t]{3}{*}{ Technology } & $\mathbf{J}$ & .615 & .615 & .615 & .615 & .615 & .615 & .615 & .615 & .615 & .615 & .615 & .615 \\
\hline & $\mathbf{N}$ & .319 & .319 & .319 & .319 & .319 & .319 & .319 & .319 & .319 & .319 & .319 & .319 \\
\hline & $\mathbf{L}$ & .066 & .066 & .066 & .066 & .066 & .066 & .066 & .066 & .066 & .066 & .066 & .066 \\
\hline & & & & & & & & & & & & & \\
\hline
\end{tabular}


On the relevance of the sub-criteria under the respective main criteria, profit after tax ranked most for financial criterion with a preference of .513. In respect of capital market indices criterion, share price ranked most with a priority of .429 , while credit policy topped among the management efficiency sub-criteria with a priority of.415. I.T. capability ranked highest among the technology sub-criteria with a priority of .615.

\subsection{Analysis of priorities in respect of the alternatives}

Table 4.6: Priorities of alternatives in respect of the sub-criteria

\begin{tabular}{|c|c|c|c|c|c|c|c|c|c|c|c|c|c|}
\hline \multirow[b]{2}{*}{ Sub-criteria } & \multirow[b]{2}{*}{ Alternative } & \multicolumn{12}{|c|}{ Bank } \\
\hline & & $\mathbf{A B}$ & AFB & DB & FB & GTB & ICB & OB & PHB & SKB & UB & UBA & ZB \\
\hline \multirow[t]{3}{*}{ Asset base (A) } & Short term & .731 & .731 & .731 & .731 & .731 & .731 & .731 & .731 & .731 & .731 & .731 & .731 \\
\hline & Medium term & .188 & .188 & .188 & .188 & .188 & .188 & .188 & .188 & .188 & .188 & .188 & .188 \\
\hline & Long term & .081 & .081 & .081 & .081 & .081 & .081 & .081 & .081 & .081 & .081 & .081 & .081 \\
\hline \multirow[t]{3}{*}{ Gross Earnings Q } & Short term & .637 & .637 & .637 & .637 & .637 & .637 & .637 & .637 & .637 & .637 & .637 & .637 \\
\hline & Medium term & .258 & .258 & .258 & .258 & .258 & .258 & .258 & .258 & .258 & .258 & .258 & .258 \\
\hline & Long term & .105 & .105 & .105 & .105 & .105 & .105 & .105 & .105 & .105 & .105 & .105 & .105 \\
\hline \multirow[t]{3}{*}{ Profit after tax $\pi$} & Short term & .230 & .230 & .230 & .230 & .230 & .230 & .230 & .230 & .230 & .230 & .230 & .230 \\
\hline & Medium term & .648 & .648 & .648 & .648 & .648 & .648 & .648 & .648 & .648 & .648 & .648 & .648 \\
\hline & Long term & .122 & .122 & .122 & .122 & .122 & .122 & .122 & .122 & .122 & .122 & .122 & .122 \\
\hline \multirow[t]{3}{*}{ Share Capital S } & Short term & .105 & .105 & .105 & .105 & .105 & .105 & .105 & .105 & .105 & .105 & .105 & .105 \\
\hline & Medium term & .258 & .258 & .258 & .258 & .258 & .258 & .258 & .258 & .258 & .258 & .258 & .258 \\
\hline & Long term & .637 & .637 & .637 & .637 & .637 & .637 & .637 & .637 & .637 & .637 & .637 & .637 \\
\hline \multirow[t]{3}{*}{ Share-price $\mathrm{P}$} & Short term & .597 & .597 & .597 & .597 & .597 & .597 & .597 & .597 & .597 & .597 & .597 & .597 \\
\hline & Medium term & .346 & .346 & .346 & .346 & .346 & .346 & .346 & .346 & .346 & .346 & .346 & .346 \\
\hline & Long term & .057 & .057 & .057 & .057 & .057 & .057 & .057 & .057 & .057 & .057 & .057 & .057 \\
\hline \multirow[t]{3}{*}{ Earning/Share E } & Short term & .615 & .615 & .615 & .615 & .615 & .615 & .615 & .615 & .615 & .615 & .615 & .615 \\
\hline & Medium term & .319 & .319 & .319 & .319 & 319 & .319 & .319 & .319 & .319 & .319 & 319 & .319 \\
\hline & Long term & .066 & .066 & .066 & .066 & .066 & .066 & .066 & .066 & .066 & .066 & .066 & .066 \\
\hline \multirow[t]{3}{*}{ Market Capitalization K } & Short term & .540 & .540 & .540 & .540 & .540 & .540 & .540 & .540 & .540 & .540 & .540 & .540 \\
\hline & Medium term & .297 & .297 & .297 & .297 & .297 & .297 & .297 & .297 & .297 & .297 & .297 & .297 \\
\hline & Long term & .163 & .163 & .163 & .163 & .163 & .163 & .163 & .163 & .163 & .163 & .163 & .163 \\
\hline \multirow[t]{3}{*}{ Bonus ratio Policy B } & Short term & .333 & .333 & .333 & .333 & .333 & .333 & .333 & .333 & .333 & .333 & .333 & .333 \\
\hline & Medium term & .333 & .333 & .333 & .333 & .333 & .333 & .333 & .333 & .333 & .333 & .333 & .333 \\
\hline & Long term & .333 & .333 & .333 & .333 & .333 & .333 & .333 & .333 & .333 & .333 & .333 & .333 \\
\hline
\end{tabular}


Table 4.6 continues

\begin{tabular}{|c|c|c|c|c|c|c|c|c|c|c|c|c|c|}
\hline \multirow[t]{3}{*}{ Dividend Policy D } & Short term & .066 & .066 & .066 & .066 & .066 & .066 & .066 & .066 & .066 & .066 & .066 & .066 \\
\hline & Medium term & .319 & .319 & .319 & .319 & .319 & .319 & .319 & .319 & .319 & .319 & .319 & .319 \\
\hline & Long term & .615 & .615 & .615 & .615 & .615 & .615 & .615 & .615 & .615 & .615 & .615 & .615 \\
\hline \multirow[t]{3}{*}{ Credit Policy, R } & Short term & .637 & .637 & .637 & .637 & .637 & .637 & .637 & .637 & .637 & .637 & .637 & .637 \\
\hline & Medium term & .258 & .258 & .258 & .258 & .258 & .258 & .258 & .258 & .258 & .258 & .258 & .258 \\
\hline & Long term & .105 & .105 & .105 & .105 & .105 & .105 & .105 & .105 & .105 & .105 & .105 & .105 \\
\hline \multirow[t]{3}{*}{ Corporate Image I } & Short term & .493 & .493 & .493 & .493 & .493 & .493 & .493 & .493 & .493 & .493 & .493 & .493 \\
\hline & Medium term & .311 & .311 & .311 & .311 & .311 & .311 & .311 & .311 & .311 & .311 & .311 & .311 \\
\hline & Long term & .196 & .196 & .196 & .196 & .196 & .196 & .196 & .196 & .196 & .196 & .196 & .196 \\
\hline \multirow[t]{3}{*}{ Structure \& Strategy W } & Short term & .493 & .493 & .493 & .493 & .493 & .493 & .493 & .493 & .493 & .493 & .493 & .493 \\
\hline & Medium term & .311 & .311 & .311 & .311 & .311 & .311 & .311 & .311 & .311 & .311 & .311 & .311 \\
\hline & Long term & .196 & .196 & .196 & .196 & .196 & .196 & .196 & .196 & .196 & .196 & .196 & .196 \\
\hline \multirow{3}{*}{ Human Capacity H } & Short term & .493 & .493 & .493 & .493 & .493 & .493 & .493 & .493 & .493 & .493 & .493 & .493 \\
\hline & Medium term & .311 & .311 & .311 & .311 & .311 & .311 & .311 & .311 & .311 & .311 & .311 & .311 \\
\hline & Long term & .196 & .196 & .196 & .196 & .196 & .196 & .196 & .196 & .196 & .196 & .196 & .196 \\
\hline \multirow[t]{3}{*}{ Age of Bank (G) } & Short term & .105 & .105 & .105 & .105 & .105 & .105 & .105 & .105 & .105 & .105 & .105 & .105 \\
\hline & Medium term & .258 & .258 & .258 & .258 & .258 & .258 & .258 & .258 & .258 & .258 & .258 & .258 \\
\hline & Long term & .637 & .637 & .637 & .637 & .637 & .637 & .637 & .637 & .637 & .637 & .637 & .637 \\
\hline \multirow[t]{3}{*}{ I.T. Capacity J } & Short term & .493 & .493 & .493 & .493 & .493 & .493 & .493 & .493 & .493 & .493 & .493 & .493 \\
\hline & Medium term & .311 & .311 & .311 & .311 & .311 & .311 & .311 & .311 & .311 & .311 & .311 & .311 \\
\hline & Long term & .196 & .196 & .196 & .196 & .196 & .196 & .196 & .196 & .196 & .196 & .196 & .196 \\
\hline \multirow[t]{3}{*}{ Product Innovation, N } & Short term & .157 & .157 & .157 & .157 & .157 & .157 & .157 & .157 & .157 & .157 & .157 & .157 \\
\hline & Medium term & .249 & .249 & .249 & .249 & .249 & .249 & .249 & .249 & .249 & .249 & .249 & .249 \\
\hline & Long term & .594 & .594 & .594 & .594 & .594 & .594 & .594 & .594 & .594 & .594 & .594 & .594 \\
\hline \multirow[t]{3}{*}{ Location/Spread L } & Short term & .094 & .094 & .094 & .094 & .094 & .094 & .094 & .094 & .094 & .094 & .094 & .094 \\
\hline & Medium term & .167 & .167 & .167 & .167 & .167 & .167 & .167 & .167 & .167 & .167 & .167 & .167 \\
\hline & Long term & .740 & .740 & .740 & .740 & .740 & .740 & .740 & .740 & .740 & .740 & .740 & .740 \\
\hline
\end{tabular}

The results in table 4.6 show that asset base, with a priority of .731, and gross earnings (.637) are of short-term relevance, profit after tax (.648) is of medium-term relevance, and share capital holders fund, with a priority of .637, is of long-term relevance. Under the capital market indices, share price, earnings per share and market capitalization are all of short-term relevance with prioritiesof $.597, .615$ and .540 , respectively. The results also revealed that respondents seem not to be bothered about bonus policy, while dividend policy is of long-term relevance with a priority of .615. 
In the case of managerial efficiency sub-criteria, credit policy (.637), corporate image (.493), structure and strategy (.493) and human capacity (.493) are all of short-term relevance, while age of bank is of long-term relevance. For the technology sub-criteria, information technology (I.T.) capacity (.493) is of short-term relevance, while products innovation and location/spread of the bank are of long-term relevance with priorities of .594 and .740 , respectively.

The overall choice of investment time horizon has revealed by the study suggests that investors in banking stocks would maximize returns in Nigeria by choosing a short-term plan with a priority of .398 .

\subsection{Computation of eigenvalues and eigenvectors}

The eigenvalues are known as characteristics values of latent roots, while eigenvectors are the characteristics vectors. The decomposition of a square matrix into eigenvalues and eigenvectors is also known as eigen decomposition or single value decomposition of eigen analysis.

Let $\mathrm{A}$ be a linear transformation represented by a square matrix $A$. If there is a vector $\mathrm{X} \in \mathrm{R}^{\mathrm{X}}=0$ such that $\mathrm{AX}=\lambda \mathrm{X}$, with eigenvalue $\lambda$, then the corresponding eigenvectors satisfy the system

(A $-\lambda I) ~ X=0$, where $I$ is the square identity matrix. As shown in Cramer's rule, a linear system of equations has $\mathrm{m} \times \mathrm{n}$ trivial solutions if the determinant varnishes. So the solutions of the above system are given by

$$
\operatorname{Det}(\mathrm{A}-\lambda \mathrm{I}) \mathrm{X}=0
$$

equation (4.4.1) is known as the characteristic equation of $\lambda$, and the left hand side is the characteristic

polynomial. A $\bar{x}=\lambda \mathrm{X}$ are called the eigenvectors; $[\mathrm{A}-\lambda \mathrm{I}]$ is the characteristic determinants of $\mathrm{A}$;

$[\mathrm{A}-\lambda \mathrm{I}]=0$ is the characteristics equation; and the values of $\lambda$ are called the eigenvalues.

The characteristics vectors for a $4 \times 4$ matrix is given by

$$
\mathrm{AX}=\lambda \mathrm{X} \quad \lambda \neq 0(\mathrm{i}=1,2,3,4)
$$

MathCAD version 7 was employed to solve for the eigenvectors.

\subsection{Computation of consistency ratios}

We have matrices $3 \times 3,4 \times 4$ and $5 \times 5$, which have the characteristic of being positive reciprocal matrices, homogenous $(b=0)$, symmetric $(a i j=1 / a i j)$, irreducible, singular, non-trivial and consists of ones $(a \mathrm{ij}=1$ for $\mathrm{i}=\mathrm{j})$. If the pairwise comparison matrix which is the judgmental values given by the respondents is consistent, then small variables of aij (which is the computation of the eigenvalues and eigenvectors) keep the largest eigenvalues close to $n$ (where $n$ is the order of the square matrix) and the remaining eigenvalues close to zero (the presence of complex numbers being due to the matrix having reciprocal values). The highest eigenvalues, $\lambda$ max, is used to calculate the consistency index, $\mathrm{CI}$, for each matrix and the $\mathrm{CI}$ is used to calculate the consistency ratio, $\mathrm{CR}$. Both $\mathrm{CI}$ and $\mathrm{CR}$ are given by

$$
\begin{aligned}
\mathrm{CI} & =\frac{\lambda_{\text {max }}-\mathrm{n}}{\mathrm{n}-1} \\
\text { and } \quad \mathrm{CR} & =\frac{C I}{\mathrm{RI}}
\end{aligned}
$$

where $\mathrm{RI}$ is the random index given by

$$
\mathrm{RI}=\frac{1.99(n-2)}{\mathrm{n}}
$$

When $\mathrm{CI}=0.1$ it is assumed that the judgemental values of the respondents are consistent. The eigenvectors of $\lambda \max$ are the vectors of $\lambda \max$ that correspond to $\lambda \max$, and the set of all vectors in the 
eigenvector is called the eigen space of $\lambda \max$ corresponding to $\lambda \max$. Furthermore, the eigenvectors satisfy the equation.

$$
\mathrm{AX}=\lambda \max
$$

If $\mathrm{CR} \leq 0.1$, the level of inconsistency is acceptable, otherwise the inconsistency of the judgmental values of the respondents is high. Using expressions (4.5.1) and (4.5.2) we compute the CI and CR, respectively, as shown in table 4.7.

Table 4.7: Consistency index and consistency ratios

\begin{tabular}{|c|c|c|c|c|c|}
\hline Main Focus & Criteria & Sub-criteria & $\lambda_{\text {Max }}$ & CI & $\mathbf{C R}$ \\
\hline & \multirow[b]{5}{*}{ Financial } & Asset base & 3.065 & 0.0325 & 0.0492 \\
\hline & & Gross earnings & 3.039 & 0.0195 & 0.0295 \\
\hline & & profit after tax & 3.004 & 0.002 & 0.0030 \\
\hline & & Shareholders fund & 3.039 & 0.0195 & 0.0295 \\
\hline & & & 4.113 & 0.0377 & 0.0380 \\
\hline & \multirow[b]{6}{*}{ Capital Market Indices } & Share price & 3.022 & 0.011 & 0.0167 \\
\hline & & Earnings/share & 3.001 & 0.0005 & 0.00076 \\
\hline & & Market capitalization & 3.009 & 0.0045 & 0.0068 \\
\hline & & Bonus ratio Policy & 3 & 0 & 0 \\
\hline & & Dividend Policy & 3.001 & 0.005 & 0.0076 \\
\hline & & & 5.4 & 0.007 & 0.0842 \\
\hline & \multirow[b]{6}{*}{ Managerial Efficiency } & Credit Policy & 3.039 & 0.0195 & 0.0295 \\
\hline & & Corporate Image & 3.054 & 0.027 & 0.0409 \\
\hline & & Structure and Strategy & 3.054 & 0.027 & 0.0409 \\
\hline & & Human Capacity & 3.054 & 0.027 & 0.0409 \\
\hline & & Age of Bank & 3.039 & 0.0195 & 0.0295 \\
\hline & & & 5.246 & 0.0615 & 0.0518 \\
\hline & \multirow[b]{4}{*}{ Technology } & I.T. Capability & 3.054 & 0.027 & 0.0409 \\
\hline & & Production Innovation & 3.054 & 0.027 & 0.0409 \\
\hline & & Location/Spread & 3.014 & 0.007 & 0.0106 \\
\hline & & & 3.001 & 0.005 & 0.00076 \\
\hline Access Bank & & & 4.121 & 0.0403 & 0.0407 \\
\hline Afribank & & & 4.162 & 0.054 & 0.0545 \\
\hline Diamond Bank & & & 4.121 & 0.0403 & 0.0407 \\
\hline First Bank & & & 4.247 & 0.0823 & 0.0832 \\
\hline Guaranty Trust Bank & & & 4.121 & 0.0403 & 0.0407 \\
\hline Intercontinental Bank & & & 4.215 & 0.0717 & 0.0724 \\
\hline Oceanic Bank & & & 4.215 & 0.0717 & 0.0724 \\
\hline Platinum Habib Bank & & & 4.121 & 0.0403 & 0.0407 \\
\hline Skye Bank & & & 4.121 & 0.0403 & 0.0407 \\
\hline Union Bank & & & 4.143 & 0.0403 & 0.0482 \\
\hline UBA & & & 4.113 & 0.0377 & 0.0380 \\
\hline
\end{tabular}


The above table shows that the judgmental values of the respondents are consistent since the consistency ratios of the pair-wise comparison matrix for all variables satisfy the required condition, that is, $\mathrm{CR} \leq 0.1$.

\section{Summary of findings, conclusion and recommendations}

\subsection{Summary of findings}

The major aim of the study is to determine whether the boom experienced in stock investment in recent time, particularly the banks' stocks, will continue in the medium to long-term in the absence of real sector development, in the light of the financial crisis that has resulted to serious economic meltdown in several sectors. We also investigated the time horizon of the appropriate investment plan for an investor in banks' stocks in the Nigerian capital market, such that would maximize returns, and which major criteria do influence investment decisions in banks' stocks. The study revealed that:

All the banks selected are well capitalized and their stocks profitable for investment particularly during and immediately after the consolidation era;

The banks operate under the same financial system and regulations and are equally rated in terms of risks associated with portfolio choice except a major economic downturn that could cripple any of the banks occurs;

The Nigerian economy is highly underdeveloped (particularly the real sector such as agriculture and manufacturing) and very volatile;

The underdeveloped Nigerian economy would not be able to support any transitory boom in bank profits and returns from investment in banks' stocks;

Most investors in Nigerian capital market are passive investors who just buy shares and keep, and not really speculating for capital gains; hence they stand at high risk of losing their capitals for any unexpected fall in stock prices or boom reversal;

Investment in banks' stock would be maximized within the short-term plan than the medium to long-term as the synthesis values support;

Financial criteria, particularly profit after tax remains the dominant factor influencing investment decision for a bank stock;

Capital market indices, particularly share prices, and bank management efficiency are other relevant variables determining investment decisions;

The situation in the Nigerian capital market show that investors will experience colossal loss for choosing long-term plans, given the weak economy, and for any eventual economy downturns, except the real sector experience real and sustainable growth;

Risk likely to adversely affect capital market and banks' shares include: changing government monetary policy; foreign capital flow reversal; poor profit of banks leading to liquidity problems; global economic recession; fall in the international price of crude oil; negative expectation effects or attitude leading to investors' apathy on capital market;

The outcome of the research supports short-term investment plan as the ultimate to maximize returns from portfolio investment in banks' stocks.

\subsection{Conclusion}

It is expected that a virile capital market operation and expedient portfolio investment decisions would lead to national as well as individual economic prosperity. This had been the case for most advanced nations, and incidentally in Nigeria during and immediately after the banks consolidation era. 
Oyatoye, Okpokpo, Adekoya AHP for portfolio selection

Our experience with the Nigerian investment scenario shows that the real sectors remain underdeveloped, thus making portfolio investment riskier, particularly, in the medium to long-term. The banking sector which appears to be the driving sector in the economy, as well as the capital market, cannot be said to be stable given economy vagaries and public policy uncertainties. This tends to exacerbate the fear and propensity for capital loss for any long-term investment decision.

Currently, the prices of the stocks have crashed and investors are already lamenting. The global economic recession has further worsened the situation. Market capitalization is dwindling, while stock broking firms are retrenching and even the banks themselves are shivering due to falling profits.

There must be appropriate macroeconomic and structural policies to support real sector economic growth. Infrastructure supplies, small and medium scale enterprise promotion, and agricultural development are inevitable in this regard. Government and quoted firms should help to bail out the capital market to mitigate against its collapse and investors' further loss.

\subsection{Recommendations}

This study actually started before the dawn of the current global economic meltdown, and as if it was a premonition, the realities of the focus problem of the study had become not only glaring but devastating. The fears being entertained by people about the seemingly booming Nigeria capital market soon became manifest. This no doubt informs the nature and scope of recommendations necessary to address the capital market investment cum economic problems of Nigeria.

There is need to recall that the current global recession is rooted to the mortgage loan crisis (sub-prime loans) which became heightened in the US in the early 2004 until the mid 2007 when the bubble burst. During the early 2004, the mortgage industry in the US enjoyed an unprecedented boom whereby mortgage brokers enticed prospective buyers with inadequate income or poor credit history into taking mortgage loans with little or no down payment. These sub-prime loans were later repackaged and sold to banks and other financial institutions which then created collateral Debt Obligations (CDOs) and sold these financial instruments to world-wide investors who unsuspectingly relied on the strength of the sellers rather than the risk rating of the underlying financial instrument. "The bubble burst in mid 2007 when sub-prime mortgage borrowers unable to service their loans, which were then due for refinancing, began to default en-mass. The mass default triggered the beginning of the global crisis because the investment banks who sold the CDOs could no longer service the debts package as repurchase notes from commercial banks" (Pedro, 2008).

Central to the crisis were two institutions - the Federal National Mortgage Association (Fannie Mae) and its sister institution, Freddie Mac, that are both government sponsored institutions set up by the US congress to facilitate and promote mortgage lending to poor or low income home buyers. The seemingly financial distress in the US crept into financial sector in the UK and further spread to other countries. The effects of the global financial crisis soon began to devastate the entire global economy.

In the context of the Nigerian economy, the macroeconomics issues have to do with problems relating to high rate of inflation; sluggish growth in output, high unemployment rate, unstable interest and exchange rates, debt burden, huge fiscal deficits, low capacity utilization, and adverse balance of payments. However, the reform efforts of the Obasanjo's regime had some credit records in terms of reducing some of these problems as Nigeria exited the Paris and London clubs debt gulags; the banking system became more solid; capital market boomed; exchange rate became reasonably stable; interest rate fairly stable; inflation manageably low; foreign exchange reserve increased as a result of increase in oil prices. The economy became more promising and predictable given these positive outcomes from the monetary cum-fiscal measures which propelled the reforms. 
Today, most of these positive indices have reversed, no thanks to the current global economic recession. Oil price now hovers between $\$ 40 \mathrm{pb}$ and $\$ 50 \mathrm{pb}$ from over $\$ 140 \mathrm{pb}$ by mid -2008 ; exchange rate drastically increased from about N120 to a dollar by December 2008 to N181 to a dollar by March 16th, 2009; interest rate has risen and inflation has also risen. These coupled with general fall in production and shrinking capital market have brought about high investment risks, thus causing a general investors' apathy.

In the light of the findings of the research and the current exigencies associated with the global economic downturn, the following recommendations are offered:

For the capital market functions to effectively perform its roles and ensure investors' gains in the face of the current economic recession and within the framework of the economy, it requires sound macroeconomic policies (fiscal and monetary) to aid the real sector;

On fiscal policy, tax incentives should be given to companies to reduce production costs and raise output; Government should increase expenditure for the provision of infrastructures, such as electricity and good roads to aid industrialization;

On monetary policy, the lending rate should be lowered for investors to expand production and attract new investments;

There should be measures to reduce inflation, possibly through properly guided foreign exchange deregulation to reduce import induced inflation;

Government should take measures to bail out any ailing bank or stock broking firm as a way of protecting investors' to reduce the apathy in investment in stocks;

The Central Bank of Nigeria and government should help to bail out the capital market through a temporal active participation in capital market transactions to raise capitalization and boost stock prices; Commercial banks should be directed to loan more money to the real sectors (agriculture, manufacturing and construction) to ensure a more productive and sustainable growth for the entire economy;

Government should give necessary encouragement to the small and medium scale enterprise sector in terms of availability of funds from banks, as well as tax relieve, so that the sector can contribute positively to the overall GDP;

The monetary authority should institute measure to check sharp practices in the ways and manners businesses are transacted in both the money and capital markets to ensure discipline and transparency in markets' operations;

On the side of the investors in capital market, the best option in Nigeria would be a short-term investment plan;

An investor needs to utilize or engage the service of stock brokers and finance experts when taking investment decisions;

Investors need to be abreast with changes in capital market indices in order to minimize the risks on investment.

\section{REFERENCES}

Aboubaker Seddik Meziani (2003). Assessing the effect of investment barriers on international capital flow using an expert -driven system. Multinational Business Review, Vol. II, No. 2.

Akintoye, R., (1999). Know your capital market. Mc. Ezlyon Educational Publishing, Lagos, Nigeria.

Brownwich, M., (1981). Economics of capital budgeting. Perguin Book, London.

Mordecai Kurz; Hehui Jin and Maurizio Motolese (2003). Determinants of stock market volatilities and risk premia. Stanford Institute for Economic Policy Research Journal (SIEPR), in Multi-National Business Review, Montclair State University, U.S. A. 
Paul J. Bolster; Vaham Janjigian and Emery A. Traham (2005). Determining investor suitability using the AHP. Financial Analysis Journal, July - August.

Pedro C. (2008). The crisis through the lens of history. Finance and Development, December 2008.

Richard Thalheimen and Mukhtan M. A. I. (2008). Time series analysis and portfolio selection: an application to mutual savings bank. Southern Economic Journal, Vol.45, No. 3.

Saaty, T. L. (1980). The analytic hierarchy process. McGraw-Hill, Inc.

Steigner J. E. (2003). The analytic hierarchy process as a means for integrated watershed management. in Bernard Kennet First Inter Agency Conference on Research on the Watershade Benson: Arizona, USA.

Thomas L. Saaty (2008). Relative measurement and its generalization in decision making: why pair-wise comparisons are central in mathematics for the measurement of intangible factors. The analytic Hierachy/Network process. Rev. R. Acad. Cien. Serie A. Mat. Vol. 102 (2), 251-318

Toshiyuki Asahi, David Tuko and Ben Shneiderman (2008). Visual decision making: using tree maps for the analytic hierarchy process. Human Computer Interaction Laboratory. Institute for Systems Research, University of Maryland, USA.

Wikipedia (2008). Analytic hierarchy process. 15th April. 